\title{
Metacognition Think Aloud Strategies In Setting Cooperative Think-Pair-Share/Square to Develop Students' Math Problem Solving Ability
}

\author{
(Comparative Study on Students of Madrasah Tsanawiyah Boarding/non-Boarding school in \\ Pekanbaru)
}

\author{
Zubaidah Amir MZ \\ Mathematics Education Department, Universitas Islam \\ Negeri Sultan Syarif Kasim \\ Mathematics Education Department, Universitas \\ Pendidikan Indonesia, \\ Riau, Indonesia \\ zubaidah_mz@yahoo.com \\ zubaidah.amir.mz@student.upi.edu
}

\author{
Wahyudin $^{2}$ \\ Mathematics Education Department, Universitas Pendidikan \\ Indonesia, \\ Bandung, Indonesia \\ wahyudin@upi.edu
}

\author{
Turmudi ${ }^{3}$ \\ Mathematics Education Department, Universitas Pendidikan Indonesia \\ Bandung, Indonesia \\ turmudi@upi.edu
}

\begin{abstract}
The problem in this research is the lack of student's Mathematical Problem Solving (MPS) ability. To overcome this problem, researchers tested the learning strategies that hone skills that are called meta-cognitive. A Meta-cognitive learning strategy is a habituation learning to control the thought process through a series of questions meta-cognition. One strategy meta-cognition is through think-aloud that can be done in a cooperative setting either in pairs (pair) as well as groups of four (square). The purpose of this study is to compare and analyze the MPS between students who received learning Metacognition Think-Aloud in cooperative (Think-Pair-Share) (MTAP), Meta-cognition Think-Aloud in a cooperative (Think-PairSquare) (MTA-S), and Direct Instruction (DI). This study is the mixed methods with quasi-experimental design posttest only the students of class VIII Madrasah Tsanawiyah (MTs)/Boarding School (PP) in Pekanbaru. The data was collected with MPS test, MPS task analysis and interviews. Data was analyzed by descriptive statistics and comparative test. Based on the analysis, it can be concluded that: 1) There is a difference of MPS between students overall based strategy (MTA-P, MTA-S, DI), based on the School system (MTs, PP), school rankings (A, B), based on their General Math Ability/KMU (high, medium, low), and gender male (M), Female (F). MPS of students at MTA-P is better than MPS of students on other two strategies; 2) There is interaction between learning strategy based on schools ranks in MPS students; 3) The most dominant indicator in the process of thinking of students in MPS is to understand the problem, and the least is to re-check the obtained solution.
\end{abstract}

Keywords-Mathematical Problem Solving; Meta-cognitive Think-Aloud; Cooperative Think-Pair-Share; Think-Pair-Square

\section{INTRODUCTION}

Math problem-solving ability is one of the specific objectives in school mathematics. One of the goals of school mathematics is the ability to solve problems that include the ability to understand the problem, devised a mathematical model, solve the model and interpret the obtained solution [1]. But the reality shows that the problem-solving activities is not a main activity in the learning process in schools. In the classroom, the emphasis of mathematics learning is still on a learning problem-solving skills by using a specific formula or algorithm, so that students are less trained to solve real problems. In solving problems, students still tend to be passive and wait for the answer given by the teacher.

Risnanosanti [2] described that to be able to solve a problem at least five aspects of students' ability to be master: the ability of mathematical concepts, the skills of mathematical algorithms, math process capability, the ability to be positive towards mathematics and meta-cognitive skills. Weinmann [3] explained that mathematical ability is a manifestation of cognitive function, and Lloyd confirms cognition will affect the style in dealing with problem solving. Therefore, meta-cognition strategies need to be trained and taught to students in the process of mathematical problem solving.

Meta-cognitive skills are the ability to control the learning process, from the planning stage, choosing the right strategy, as the issue at hand, and then monitor progress in learning and simultaneously correcting any errors that occur during understand the concepts, analyze the effectiveness of the selected strategy. 
One strategy meta-cognition is Think Aloud. In this strategy, teachers should promote the habit of thinking out loud when students solve problems [4]. Meta-cognitive thinkaloud, can be done on a cooperative setting, one of which forms Think-Pair-share or Square. Authors interested in using Cooperative TPS based on the research of Luis. He stated that the Pair-Listener Thinker can be made in the scale of a wider group,'The results suggest that Thinker-Listener approach can be effectively extended on to a larger scale of pairs for longer periods of time to observe the effectiveness in developing students' meta-cognitive strategies" [5].

Most studies like Schoenfeld, Kramarski and Mevarech and van Hoek, den and Terwel Eden, meta-cognitive teaching is done in a cooperative setting where a small group of 4-6 students learns together [4,p.61]. Application of metacognitive teaching in cooperative learning setting can present the right conditions for students to elaborate on their mathematical reasoning [6]. In line with the above opinion, Abdurrahman stated that the cooperative learning can be developed meta-cognitive skills for cooperative learning occurs communication among group members [3, p.178].

Research to be conducted school system, the capability of general math students ability (KMU), school rank, and gender as control variables. The variables shown differences of learning facilities, students' learning styles, motivation, learning outcomes math based on the various applications of different learning strategies [7]. Therefore, this study examines the deeper effects of the application of learning Meta-cognition Think Aloud in Setting Cooperative ThinkPair-Share/Square to the ability of mathematical problem solving (MPS) of the student.

\section{A. Mathematical Problem Solving Ability}

The problem is a question that must be answered. However, not all questions are an issue. In [8] it was stated that a question is a problem when challenged to answer questions that the answer can not be done on a regular basis only. However, problems in math is a subject that the students themselves were able to finish without using a method or routine algorithm [8].

Some indicators of mathematical problem-solving ability by NCTM in grade 5-8 is as follows: use problem-solving approaches to investigate and understand mathematical content ;formulate problems from situations within and outside; develop and apply a variety of strategies to solve problems, with emphasis on multistep and non-routine problems; verify and interpret result with respect to original problem situation; generalize solution and strategies to new problem situations; acquire confidence in using mathematics meaningfully [9].

Based on the description of several indicators of math problems solving above, it can be concluded that a student has a mathematical problem-solving ability is student had been able to; (1) understand the problems with identifying the elements that are known, (2) selecting and implementing strategies properly and systematically to solve the problem, (3) explain and interpret the results by examining its own accuracy and correctness strategy solutions obtained.
According to Wahyudin there are some tips for students (problem solver), namely: compare the problem to help connect new problems with which have been resolved before; think of your thoughts with pauses to question "how is this going to help me solve this problem?"; share your thoughts with others by explaining ideas to help yourself think better; and organizing work to help think clearly [10]. Bransford states that well aware of what they are doing and often monitor, or review their own progress themselves, or adjust their strategies and solve problems. [11] Based on tips above, that in learning problem solving approach can be implemented through metacognitive strategies in cooperative Think-Aloud Think-Pair-Share (MTA-P) and Think-Pair-Square (MTA-S).

\section{B. Metacognitive Think Aloud Strategy}

There are various definitions of metacognitive. Schoenfeld defined as the knowledge of thinking process, self-regulate for problem solving, which makes it difficult to use as a concept [4,p.58]. Campione, Brown and Connell stated that "successful students can reflect on their own problem-solving activities, have a strong strategy for dealing with new problems, and monitor and adjust the strategy in an efficient and effective" [12].

Toit and Kotze explains [4,p.58] that metacognitive strategy refers to the conscious monitoring of one's cognitive strategies to achieve specific goals, such as when students ask to ask themselves about the task and then observe how well they answer the questions. Toit et.al explained that grouping strategies metacognitive in 13 variations. Namely: Planning strategy, generating a question, ... thinking aloud, cooperative learning, and modeling. In the strategy think aloud, Toit and Kotze explain that teachers should promote the habit of thinking out loud when students solve problems and will help the students to identify the capacity to think students are taught to use the following four questions when solving a problem: What troubles me ?; How can I do it ?; Do I use my plan ?; and How do I do? [4,p.61].

\section{Cooperative Learning}

A Cooperative study by Johnson \& Johnson, quoted Hartono that use small-group learning, the learners work together to be maximum their learning. According to Slavin that Cooperative learning is a model of learning in which learners learn and work in small groups whose members collaboratively 4-6 people with a heterogeneous group structure [13]. Heterogeneous group means, group consists of members who have academic ability, gender, and social backgrounds different.

Strategy Think-Pair-Share (TPS) by Arends first developed by Frank Lyman at the University of Maryland [14]. Further Arends that the Think-Pair-Share is an effective way to diversify the atmosphere of a pattern of class discussion, to provide time for students to read the task, the situation is a question mark, and teachers compare the debriefing to the group, Step-by-step learning phase is as follows: 1). Thinking: Teachers ask a question or problem that is associated with learning, ask students to think for themselves some time. 2). Pairs (pairing): The teacher asks the students to pair up and discuss what they have acquired. Interactions can unite answer or idea of an identified problem. In normal time given 4-5 
minutes, 3). Sharing (Sharing): The teacher asks the pairs to share to whole class that has them talking. It is effective to go around the room from partner to partner and to continue until around some couples can be reported [14].

A structural approach to cooperative learning Think-PairShare (TPS) is a learning technique that was developed by Spencer Kagan. Anita Lie suggested that this technique gives learners the opportunity to work independently and in collaboration with others and has another advantage, namely the optimization of the participation of learners.

There are three main components in the Think-Pair-Square structural approach which is as follows. Learning TPS also provides an opportunity for individual learners more time to think, to answer and help one another fellow group members. Think, teachers assign tasks to individual learners and then allow time for learners to think about and do the job; Pair, Learners are paired with one of the partners in the group and discuss with the partner; Square, two couples meet again in groups of four students have the opportunity to share their work to groups of four and think again in the group [15].

In addition, in the second cooperative learning at the time a student Pair stages and Square, indirectlyve done metacognitive strategies Think-aloud. The learning techniques give emphasis on the use of certain structures that are designed to affect the pattern of interaction of learners. Each learner was given the responsibility to be master a subject matter, thus encouraging learners to try to understand the material that will ultimately affect the learning outcomes of students, both for himself and the group.

\section{RESEARCH METHOD}

This research uses the Mixed Methods. The population in this study were all students of Madrasah Tsanawiyah (MTs)/Pondok Pesantren (PP) in Pekanbaru. The sample determined by stratified sampling technique, which is taken based on school system boarding school and non-boarding (PP/MTs), school rank (A, B), a general mathematical ability (KMU), and gender (M, Fm). This is done by the data rank MTs /PP of Kemenag Riau province. Samples were students of class VIII MTs/PP in Pekanbaru taken from schools classified as high rank (A), medium (B). Furthermore drawn at random each selected schools each of the three classes, two classes designated as experimental class is the class that received the learning meta-cognitive Think Aloud in cooperative TPS (MTA-P), (MTA-S) and one other class as a control group that received direct instruction (DI) strategy. Samples were taken from class VIII MTs/PP with estimated that they have been able to adapt to environmental conditions and forecasts relatively the same basic capabilities.

The analysis of data is done to exam the differences of MPS students by each group, and to exam the interaction between variables accordance with the hypothesis research. The analysis using t-test, One and two-way ANOVA with Scheffe test post-hoc by SPSS-21 for-windows. The qualitative data obained through case studies (case study) through analysis of students' answers to the question, followed by the MPS from published interviews given task students by descriptive analysis.

\section{RESULTS AND DISCUSSION}

The data of MPS student test described and analyzed based group learning strategies based of the school system, the school rank, general math ablity student (KMU), and Gender. Based on the results of the analysis will be disclosed MPS students as a result of their treatment.

As a general overview of students's MPS after giving treatment based Learning Strategy, on the school system, school rankings, Gender and KMU generally in details are presented in Table 1. Table 1 illustrates that the average tests score MPS students who received each relatively learning based on the schools system (MTs, PP), schools rank (A, B), Gender (Male, Female) and group KMU (High, Medium and low). In general bar chart that describes the average test score MPS is presented in Figure 2, Figure 3, Figure 4 and Figure 5 and Figure 6. The bar chart above provides information that there are differences between the mean scores test MPS among students at each study variable (school system, school rankings, KMU and Gender). The results of comparative and interaction test concluded in conclusion.

The results showed that the MPS students who obtain teaching MTA-P is significantly better than students who acquire learning MTA-S and the DI. It is shown with the average score MPS of students MTA-P, DI, and MTA-S respectively (21.86), (19.59) and (15.11).

It suggests that the MTA-P learning more effective in developed MPS students. This happens because the MTA-P students are given the opportunity to dialogue with habituation in pairs asking questions meta-cognition in solving mathematical tasks. This supports the idea Blakey and Spence that mention a pair of students, where the students explain their thinking processes while his partner helped to clarify his thinking by listening and asking questions. [4,p.61].

Through meta-cognitive-think-aloud in pairs better enable students to communicate effectively, interactive and cooperate in the control of their learning, realizing what they were doing, to observe directly together, progress themselves, adjust their strategies and solve problems. This is in line with the opinion of Wahyudin that some tips to become a good problem solver them share their thoughts with others by explaining ideas to help yourself think better; and organizing work to help think clearly [10]. It could be possible to appear on learning MTAP.

The effectiveness of learning Meta-cognition ThinkAloud-Pair both related presentation materials, treatment by teachers, and classroom interaction developed, could complement the results of other studies are consistent example of Luis [6] as the Thinker and The Listener, Sweeney [16], Noornia [17]. Luis did a qualitative study on the use of metacognitive (pair-problem solving, thinker-listener) with a sample of the primary student of mathematics. Luis research recommendations was piloted in groups larger scale and in a different sample. His study concern to developed metacognitive strategies on pair student to student's MPS. While Hepsi in her develop research, developed metacognitive based teaching materials and assessing its impact on the ability of high school students think reflectively. Noornia 
meta-cognitive apply learning in a cooperative setting and its effect on mathematical problem solving ability, but not confirmed a specific technique/strategies metacogitive and a specific technique/strategies cooperative were ones used in his research. Different from the risets above, the results of this study reinforce the importance specific of using metacognitive Think-Aloud, where the sample on MTs students, in pairs and in large groups. This study to comparative student's MPS with MTA-P, MTA-S, and DI strategies. In this study, the authors also developed the student work sheet (LAS) based meta-cognitive by appending the questions metacognition in the process of task completion LAS. This study contributes reviewed several aspects such as the school system, school rankings, KMU level, and gender. Beside that, this research also concluded that the tendency of MPS ability indicator in completing MPS test.

As previously disclosed, the ability of MPS students in terms of learning strategy, learning MPS students who obtain MTA-P is better than MPS students on two other strategies. In addition to the MPS students are reviewed in terms of the school system (PP, MTs), the higher MPS by students PP than the MPS of student MTs. Based school rankings, MPS of students school of A higher than the MPS of student rank B. Based the level of student's KMU, specialized in strategy MTA-P, the average MPS highest in a row level by students KMU medium, low, and high. As for the gender aspect, overall there are different of MPS students, with the average MPS female students is higher than male. But specifically in learning MTA-P, MPS students higher male than female, while the strategy of MTA-S and the DI average is the highest MPS is still dominated by the female.

In the process of mathematical problem solving, the most dominant indicator is to understand the problem. In general, students have demonstrated a good understanding of the problem, it is seen students are able to identify what is known and requested by matter.

For indicator selecting and implementing the completion strategy, vary among students of high ability, medium, and low. For high ability students, students can to identify problem, choose the concepts and procedures that are relevant to a given problem, students are able to perform calculations correctly. These students understand the problems through mental objects contained in the problem, in other words doing reflective abstraction in understanding the problem. As stated by Piaget that reflective abstraction (focusing on mental objects) [18].

For student-skilled, most students already use concepts that are relevant to the issues, but students mostly wrong in using arithmetic operating procedures, the accuracy was lacking, especially by entering the wrong variable values. In addition, students have the ability, sometimes trying to resolve the problem by way of direct calculation, taking and or counting objects. Thus we can say that he did a pseudo-empirical abstraction as Piaget suggests that the apparent empirical abstraction focuses on the action object and its properties [18].

For lower ability students find it difficult to understand the problem, determine the related concept or formula. So most students are not able to resolve the problem, the answers tend to be empty or just written the given problem.

It is very rarely written by students in mathematical problem solving is not re-write the checking process of the obtained solution. Based on interviews with student researchers, revealed that students in high ability students still do the checking, but the process is done in graffiti. Students express forgot to write in the answer, because it was all but certain overall. While the students' abilities were, most students did not make the process of checking, controlling meta-cognition this represents less than high ability students. For low ability students, researchers did not interview the students, because the resolution process is not completed.

TABLE I. SCORE OF MPS TEST BASED ON SCHOOL SySTEM, SCHOOL RATING, GENDER, AND GENERAL MATH ABILITY (KMU)

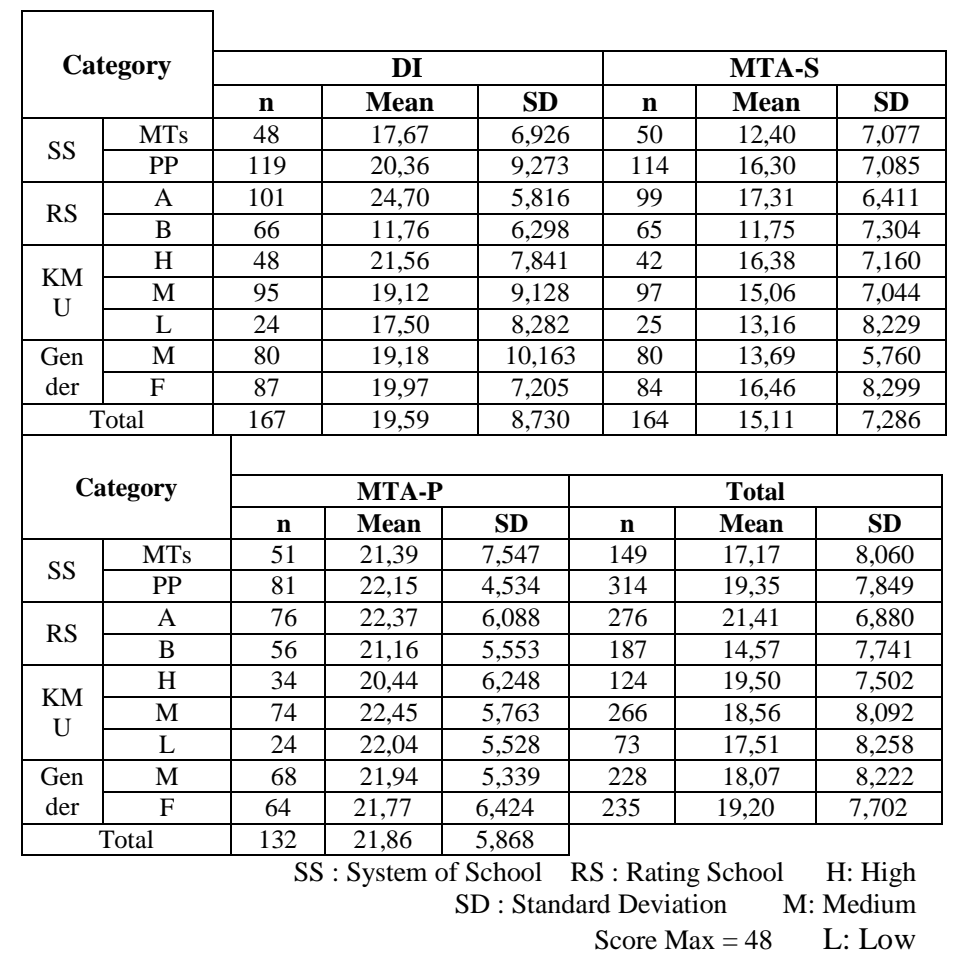

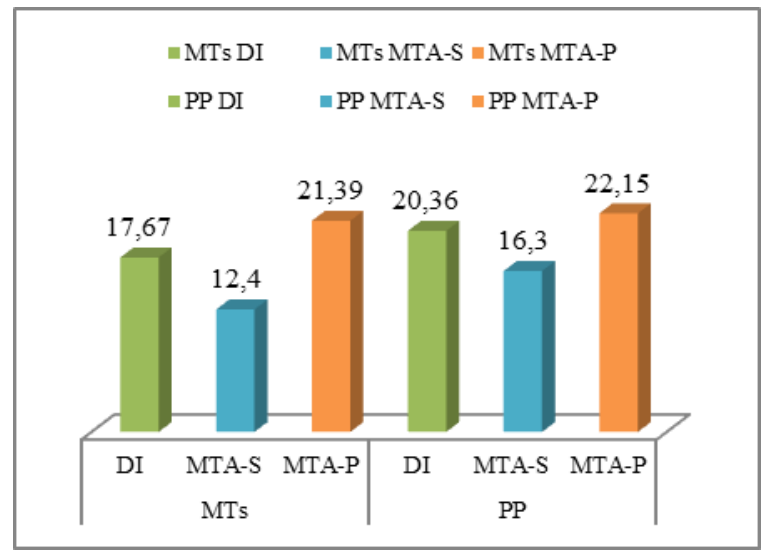

Fig. 1. MPS based System School 


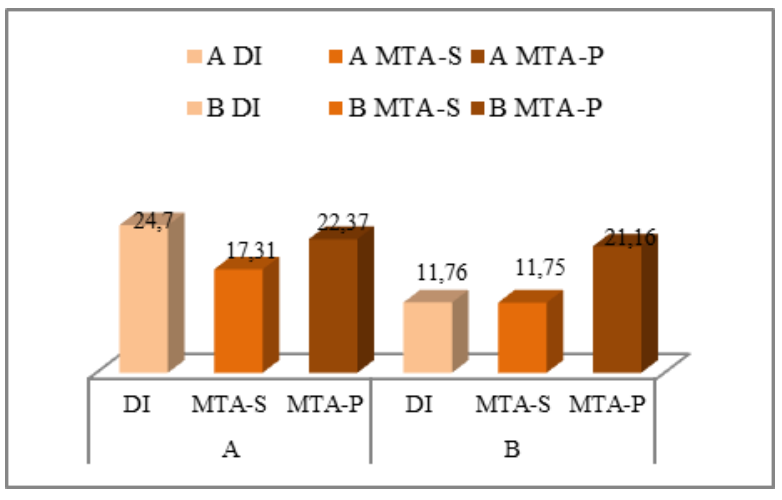

Fig. 2. MPS Based Rating School

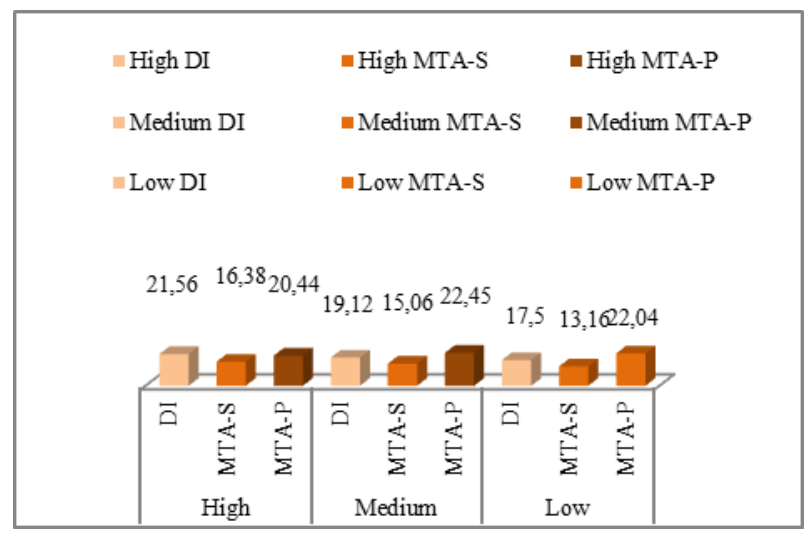

Fig. 3. MPS Based KMU

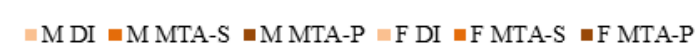

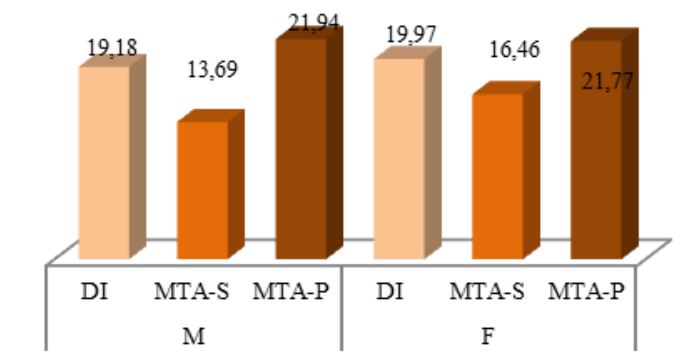

Fig. 4. MPS Based Gender

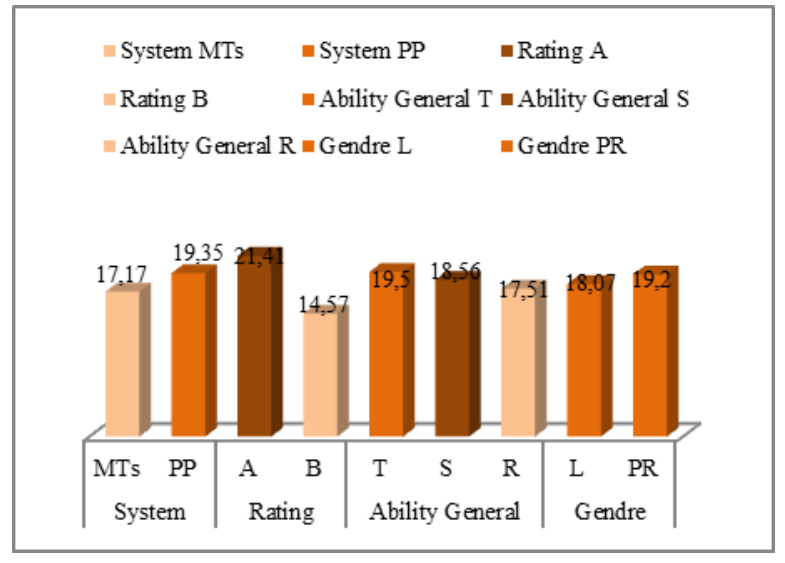

Fig. 5. MPS General Variabel

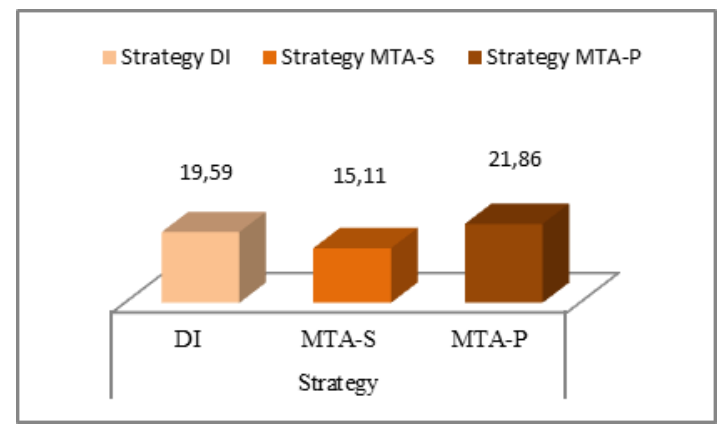

Fig. 6. MPS TOTAL

\section{CONCLUSION}

Based on the results of research and discussion it can be concluded as follows.

a. Overall there are significant differences between Mathematical Problem Solving (MPS) of students who take the learning Meta-cognition Think-Aloud in setting cooperative Pair (MTA-P), by setting cooperative Square (MTA-S), and direct instruction Direct Instruction (DI).

b. There are significant differences between the MPS students who take the learning Meta-cognition ThinkAloud in setting cooperative Pair (MTA-P), by setting cooperative Square (MTA-S), and direct instruction Direct Instruction (DI) based school system (PP, MTs)

c. There are significant differences between the MPS students who take the learning Meta-cognition ThinkAloud in setting cooperative Pair (MTA-P), by setting cooperative Square (MTA-S), and Direct Instruction (DI) based school rank (A, B )

d. There are significant differences between the MPS students who take the learning Meta-cognition ThinkAloud in setting cooperative Pair (MTA-P), by setting cooperative Square (MTA-S), and direct instruction Direct Instruction (DI) based level of the ability of Mathematics General (KMU ) students (High, medium, low)

e. There are significant differences between the MPS students who take the learning Meta-cognition Think- 
Aloud in setting cooperative Pair (MTA-P), by setting cooperative Square (MTA-S), and direct instruction Direct Instruction (DI) based gender groups of students (M,Fm)

f. There is no interaction between learning strategies (MTAP, MTA-S, and DI) and the school system (PP, MTs) in MPS students.

g. There is an interaction between learning strategies (MTA$\mathrm{P}$, MTA-S, and DI) and ranked schools (A, B) in the MPS students.

h. There is no interaction between learning strategies (MTAP, MTA-S, and DI) and KMU levels (high, medium, low) in the MPS students.

i. There is no interaction between learning strategies (MTAP, MTA-S, and DI) and gender (LK, PR) in MPS students.

j. The highest indicator of MPS is the student can understand the problem, but the lowest MPS indicator is re-check the completed test worksheet.

The implications of this research are the implications of this conclusion are:

a. Statistically, there is no equality MPS students in the group strategy MTA-P in each school system. From these findings, we concluded that learning MTA-P is suitable to be applied to every school system in improving MPS students

b. Statistically there is a difference MPS students in group learning strategies MTS-S on the school system (PP, MTs). More MPS students in PP higher than MPS students MTs. From these findings, we concluded that learning MTA-S is suitable to be applied on the school system in the PP improve MPS students.

c. Overall there are a difference MPS students B. MPS students ranked higher in group A than school rankings B, both the MTA-P strategy, and the strategy of MTA-S. However, there MPS equality in the school ranked second in the use of DI strategy. From these findings, we concluded that learning and MTA MTA-P-S is suitable to be applied to the A rank schools in improving student MPS.

d. Statistically, MPS students who followed the MTA learning-P were higher in each level of KMU students. From these findings we concluded that learning MTA-P is suitable to be applied at all levels of KMU students in improving MPS students.

e. Mathematical problem solving abilities of female students is higher than male students at MTA-S strategy. From these findings, we concluded that learning MTA-S fits better with the female students in developing student MPS.

f. It is necessary to remind the students to re-check the completed MPS test result before submitting it to the teachers.

\section{Acknowledgment}

Thank to all academic staffs of MTs Al-Muttaqin Pekanbaru and Al-Fajar Pekanbaru, Pondok Pesantren Darel Hikmah Pekanbaru and Pondok Pesantren Al-Munawwarah Pekanbaru which have provided additional data related to this case study.

\section{References}

[1] Badan Standar Nasional Pendidikan (BSNP), Model Penilaian Kelas, Jakarta: Depdiknas, 2006.

[2] Risnanosanti, Melatih Kemampuan Metakognitif Siswa Dalam Pembelajaran Matematika. Proseding seminar Nasional Matematika dan Pendidikan Matematika, 2008, p.115.

[3] Abdurrahman, M., Pendidikan Bagi Anak Berkesulitan Belajar. Jakarta: Rineka Cipta, 1999, p.127

[4] Toit, Stehpan du dan Kotze, Gary, Metacognitive Strategy in the Teaching and Learning of Mathematics. Pythagoras. http://www.pythagoras.org.za/index.php/pythagoras/article/view/39, 2009, pp.69

[5] Luis, T. etc. Thinker-Listener Pair Interactions to Develop Student's Metacognitive Strategies for Mathematical Problem Solving ,Nanyang Technology University,Singapore.2006.

[6] Kramarski, Bracha et al. The Effects of Metacognitive Instruction on Solving Mathematical Authentic Tasks. Educational Studies in Mathematics. Vol. 49, No.2, 2002.

[7] Suryadi, Didi, Penggunaan Pembelajaran Dengan Pendekatan Tidak Langsung Serta Pendekatan Gabungan Langsung Dan Tidak Langsung Dalam Rangka Meningkatkan Kemampuan Berpikir Matematika Tingkat Tinggi Siswa SLTP, 2005. Disertation UPI. unpublished.

[8] MKPBM UPI. Common Textbook. Strategi Pembelajaran Matematika Kontemporer. Bandung: JICA UPI Bandung. 2001, p.83.

[9] NCTM, Currriculum and Evaluation Standars For Scool Mathematics. Sevent Printing. Reston, Virginia: NCTM, 1989, p.79

[10] Wahyudin., Pembelajaran \& Model Pembelajaran; Pelengkap Untuk Meningkatkan Kompetensi Pedagogis Para guru dan Calon Guru Profesional. Bandung. Bandung: CV. IPA Abong, 2008.

[11] NCTM. Principles and Standards for Shcool Mathematis, Reston, Virginia: NCTM, 2000.

[12] Gartmann, Shirley and Freiberg, Melissa. Metacognition and mathematical Problem Solving: helping student to ask The Right Questions. Jurnal TME Online, vol 6, number 1. by the Mathematics Education Student Association at The University of Georgia. All rights reserved, 2012

[13] Isjoni. Cooperative Learning, Bandung, Alfabeta, 2007.

[14] Trianto, Mendesain Pembelajaran Inovatif-Progresif. Jakarta: Prenada Media, 2010,p.81.

[15] Lie, Anita, Cooperative Learning, Jakarta, Grasindo, 2007, p.43.

[16] Sweeney, Carly Mara, The Metacognitive Functioning of Middle School Students with and without Learning Disabilities During Mathematical Problem Solving. Open Access Dissertations. Paper 433, 2010.

[17] Noornia, anton, Pembelajaran Metakognitif Dalam Setting Kooperatif Untuk Menumbuhkan Self-Regulated Learning Dan Meningkatkankemampuan Berpikir Kritis Serta Problem Solving Matematika. 2013. Disertation UPI. Unpublished.

[18] Tall, D. Reflection on APOS theory in Elementary and Advanced Mathematical Thinking. Presented at PME23 Haifa, Israel, July, 1999. Proceding of the $23^{\text {rd }}$ Conference of PME, Hafia Israel, I: 111-118. http://www.warwick.ac.uk/staff/David.Tall/pdfs/dot1999c-apos-in-amtpme.pdf. 